\title{
Cardenolide and glucosinolate accumulation in shoot cultures of Erysimum crepidifolium Rchb.
}

\author{
Elisa Horn ${ }^{1} \cdot$ Yvonne Kemmler $^{1} \cdot$ Wolfgang Kreis ${ }^{1}$. Jennifer Munkert ${ }^{1}$ (D) \\ Received: 16 September 2020 / Accepted: 27 October 2020 /Published online: 4 December 2020 / Editor: Gregory Phillips \\ (C) The Author(s) 2020
}

\begin{abstract}
Erysimum crepidifolium Rchb. is one of the few Brassicaceae species accumulating glucosinolates as well as cardenolides. This is possibly providing a selective advantage in evolution as both compounds are part of a chemical defense system. In order to study the biosynthesis of these compounds, a regeneration protocol for E. crepidifolium using in vitro shoot cultures derived from seeds has been developed. Murashige and Skoog (MS) culture medium supplemented with various combinations of cytokinins and auxins was used. MS medium containing NAA (naphthaleneacetic acid, $0.04 \mathrm{mg} \mathrm{mL}^{-1}$ ) and BAP (6-benzylaminopurine, 0.2 . $10^{-2} \mathrm{mg} \mathrm{mL}^{-1}$ ) proved to be optimal for root formation. Plantlets developed well on modified MS medium without the use of phytohormones. About $80 \%$ of the plantlets rooted in vitro developed into intact plants after transfer to the greenhouse. Cardenolides (1.75 $\mathrm{mg} \mathrm{g}^{-1}$ dry weight (DW)) were detected in cultured shoots on solid DDV media while glucosinolates mainly accumulated in roots where $0.025 \mathrm{mg} \mathrm{g}^{-1} \mathrm{FW}$ were detected in shoots cultured on the same medium (DDV). The expression of two progesterone $5 \beta$-reductase and three $\Delta^{5}-3 \beta$-hydroxysteroid dehydrogenase genes were measured in shoot cultures since the encoded enzymes are supposed to be involved in cardenolide biosynthesis. E. crepidifolium shoot cultures propagated on solid media meet the necessary requirements, i.e., clonal homogeneity, product accumulation, and gene expression, for a suitable model to study cardenolide but not glucosinolate biosynthesis.
\end{abstract}

Keywords Erysimum crepidifolium Rchb. · Regeneration · Glucosinolates · Cardenolides

\section{Introduction}

Arabidopsis thaliana (L.) Heynh., a member of the Brassicaceae family, is widely used as a model organism in genetic studies. The genus Erysimum L. belongs to the same family and comprises more than 200 species (Bailey et al. 2006; Polatschek 2013a, b). The production of cardenolides by species in the genus Erysimum is one of the best-studied examples of an evolutionarily recent gain of a novel chemical defense (e.g., Jaretzky and Wilcke 1932; Makarevich et al. 1994; Züst et al. 2020). Most Brassicaceae species accumulate glucosinolates which are activated by myrosinases to produce repellent mustard oils (Fig. 1; Fahey et al. 2001). However, several herbivores have evolved to overcome this defense

Jennifer Munkert

jennifer.munkert@fau.de

1 Pharmaceutical Biology, Department of Biology,

Friedrich-Alexander-University, Staudtstr. 5,

D-91058 Erlangen, Germany mechanism (Winde and Wittstock 2011). Cardenolide biosynthesis may have evolved further since the 'mustard oil bomb' (Matile 1980) to provide a new type of repellent. In fact, several glucosinolate-adapted beetles refused to feed on dietary cardenolides at levels found in Erysimum species (Nielsen 1978a, b).

Cardenolides and cardenolide-containing plant extracts including Erysimum species (Zhu et al. 1989; Burger and Wachter 1998) have been used for centuries in the therapy of heart insufficiency in humans. The biosynthesis of cardenolides has mainly been studied in Digitalis (Kreis and Müller-Uri 2010, 2013; Kreis 2017). The likely existence of a very similar cardenolide pathway in Erysimum has not been demonstrated. Munkert et al. $(2011,2014)$ proposed Erysimum species as model plants for the study of cardenolide biosynthesis in Brassicaceae when investigating the enzymes involved and their respective genes. This idea was further elaborated by Züst et al. (2018).

In previous efforts, greenhouse plants originating from seeds were used (Munkert et al. 2014); however, the generation of reliable data is often hindered by the limited 


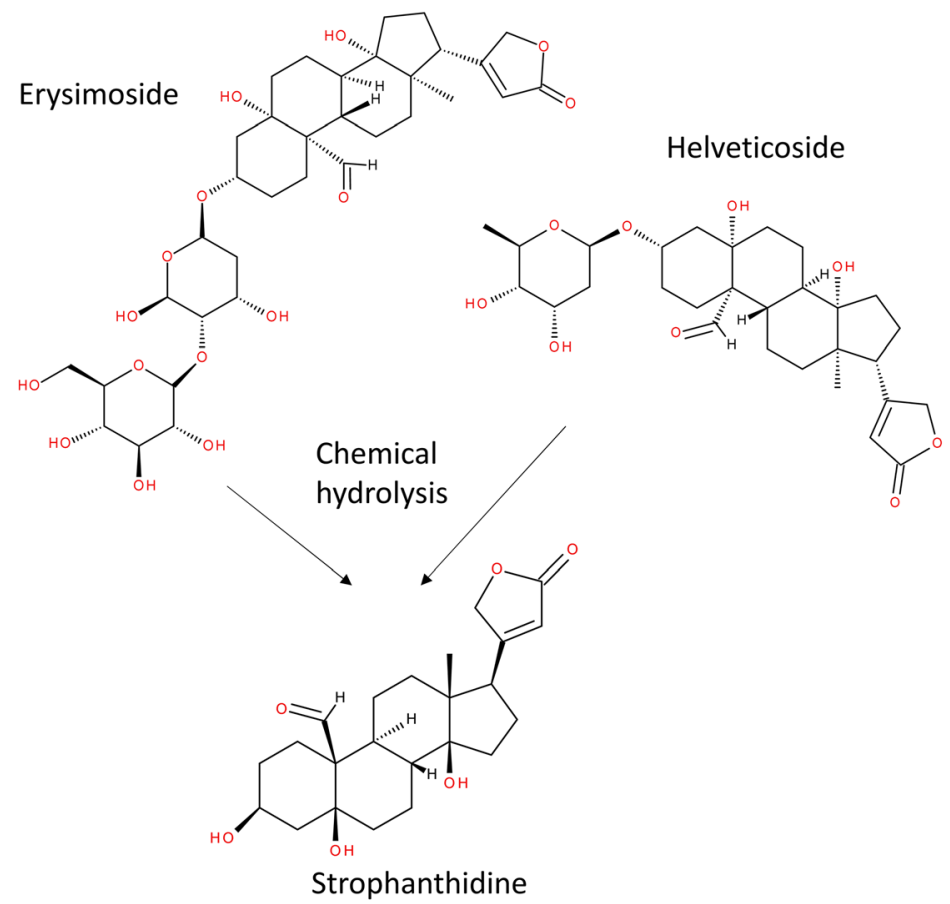

Glucoiberin
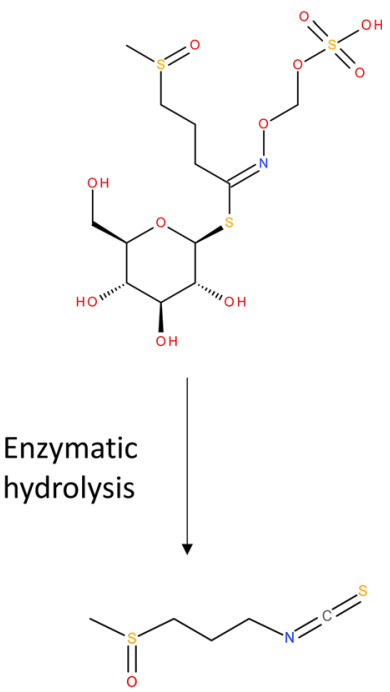

Iberin

Figure 1. Structures of the major cardenolides (erysimoside, helveticoside) and the major glucosinolate (glucoiberin) present in Erysimum crepidifolium Rchb. shoot cultures and their respective aglycones released after hydrolysis.

availability of homogeneous plant material (Schöner et al. 1986; Kreis et al. 2015). Therefore, the main purpose of this work was to develop a rapid micropropagation protocol for genetically homogenous E. crepidifolium shoot cultures and plants. Plant growth, cardenolide content, and glucosinolate content were quantified during plant regeneration and until permanent shoot cultures were established (Fig. 1,2).

\section{Materials and methods}

Chemicals Myrosinase was prepared from Sinapis alba (mustard) seeds as described by Meitinger and Kreis (2018). All cardenolides analyzed (erysimoside, helveticoside, kstrophantoside, $\beta$-methyldigitoxin; Fig. 1) were sourced from our reference collection or from Merck KGaA (Darmstadt, Germany). All other chemicals including MS medium, growth regulators, or solvents were purchased from Carl Roth $\mathrm{GmbH}$ \& Co.KG (Karlsruhe, Germany) or from Merck KGaA (Darmstadt, Germany).

Plant regeneration Seeds from wild plants of E. crepidifolium were surface-sterilized in $4 \%$ calcium hypochlorite, washed in autoclaved distilled water, and germinated aseptically on solid Murashige and Skoog (MS) medium (Murashige and Skoog 1962) containing $30 \mathrm{~g}$ glucose and $2.25 \mathrm{mg} \mathrm{6-}$ benzylaminopurine (BAP) per liter (solid DDV medium). After 6 to $8 \mathrm{wk}$, developing shoots were transferred to liquid MS medium containing 30 g glucose and $2.25 \mathrm{mg}$ BAP per liter (liquid DDV medium). After 6 wk of adaption to the liquid media, the shoots were transferred to a liquid MS medium containing $30 \mathrm{~g}$ glucose and varying concentrations of naphthaleneacetic acid (NAA; 0 to $80 \mathrm{mg}$ ) and BAP (0 to $2.25 \mathrm{mg}$ ) per liter to initiate rooting. The optimal composition was established at $40 \mathrm{mg}$ NAA and $0.02 \mathrm{mg}$ BAP per liter (liquid EDDV medium) (Fig. 2c). After $40 \mathrm{~d}$ in rooting medium, plantlets with well-developed roots were transferred to solid $\mathrm{OH}$ medium that is based on DDV medium with increased amounts of $\mathrm{KH}_{2} \mathrm{PO}_{4}\left(340 \mathrm{mg} \mathrm{L}^{-1}\right)$, glycine ( $\left.4 \mathrm{mg} \mathrm{L}^{-1}\right)$, and glucose $\left(33 \mathrm{~g} \mathrm{~L}^{-1}\right)$ but without additional phytohormones. After $2 \mathrm{mo}$, the plantlets were transferred to autoclaved soil and allowed to acclimatize. They were kept in seeding boxes for about $3 \mathrm{wk}$ and were sprayed with water twice a day during the first week to guarantee a humid atmosphere. In order to reduce the humidity during the acclimatization period, spraying with water was reduced gradually (Arikat et al. 2004). Following this procedure the plants were cultivated at standard greenhouse conditions (Fig. $2 d$ ).

Permanent shoot cultures Shoots developed different phenotypes depending on whether they were kept in liquid DDV or on solid DDV medium (Fig. 2a,b). This resulted in two types of permanent shoot cultures, and the cardenolide and glucosinolate contents (see below) have been determined for both. All stock cultures were kept under permanent white light (fluorescent lightning, approximately $40 \mu \mathrm{mol}$ photons $\mathrm{m}^{-2}$ $\mathrm{s}^{-1}$ ) and at 21 to $24^{\circ} \mathrm{C}$. Permanent cultures cultivated in liquid media were kept on MULTITRON gyratory shakers (Infors 
Figure 2. Erysimum crepidifolium Rchb. germinated in vitro. (a) Permanent cultivation in liquid DDV medium. (b) Rooting in vitro in liquid medium. (c) Rooted cultivation on solid DDV medium. (d) Regenerated plants grown in the greenhouse.

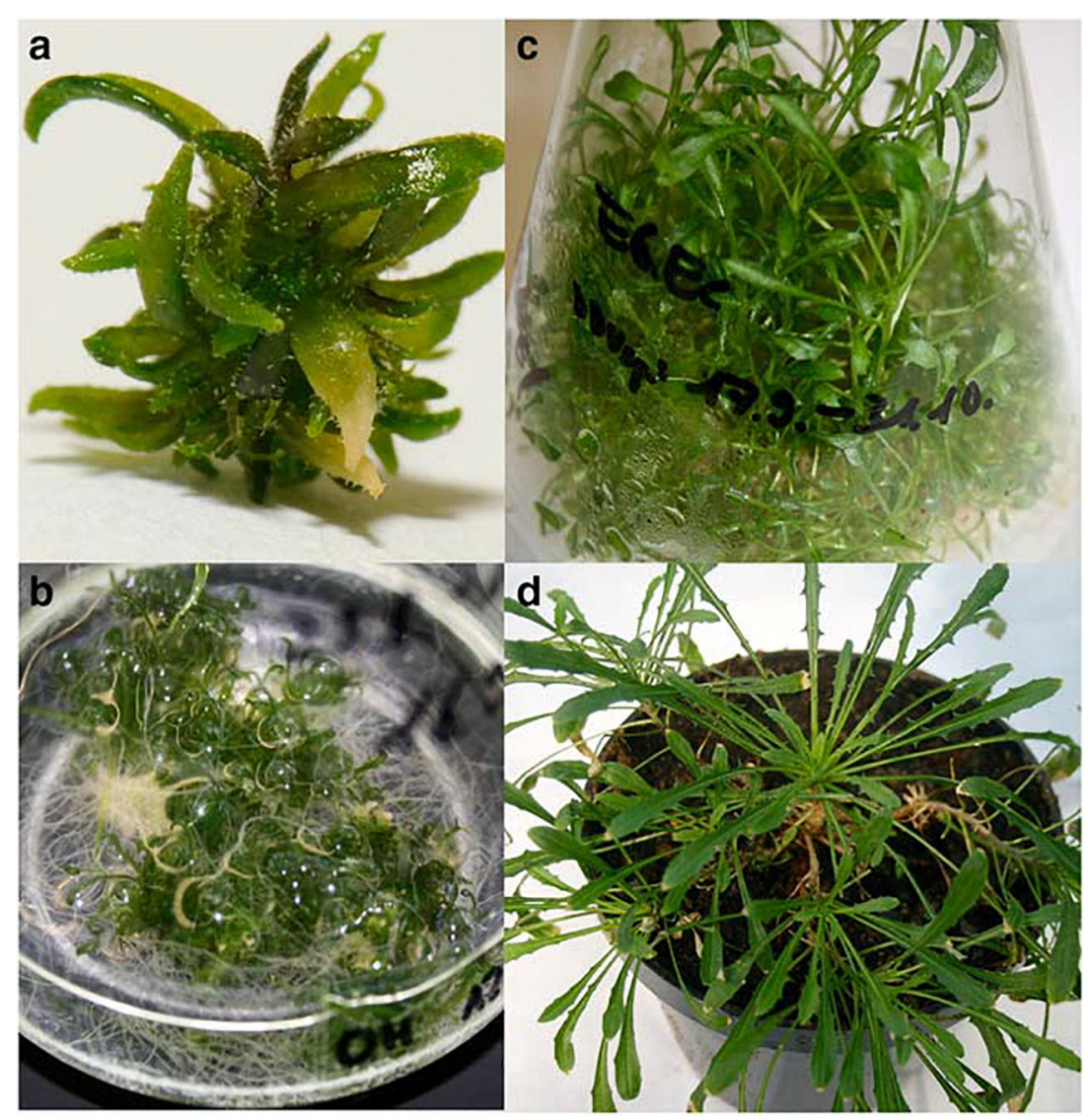

GmbH, Sulzemoos, Germany) at $55 \mathrm{rpm}$. Stress treatment with either 2-cyclohexene-1-one or methylvinyl ketone (MVK) was applied as described by Munkert et al. 2014.

RNA extraction and CDNA synthesis RNA was isolated from the individual tissue samples. These samples were frozen with liquid nitrogen and then ground to a fine powder using mortar and pestle. Total RNA was extracted using the illustra ${ }^{\mathrm{TM}}$ RNAspinMini RNA Isolation Kit (GE Healthcare, Munich, Germany). cDNA was synthesized employing the SuperScript ${ }^{\mathrm{TM}}$ III First-Strand Synthesis for reverse transcription PCR (RT-PCR) Kit (Invitrogen, Karlsruhe, Germany).

Quantitative real-time analysis (qPCR) Real-time PCR was carried out in the StepOnePlus Real-Time PCR System (Life Technologies, Erlangen, Germany) using the SYBR Green Mastermix Kit (Applied Biosystems, Erlangen, Germany) according to the manual provided. The relative gene expression levels were calculated using the $2^{-\Delta \Delta \mathrm{Ct}}$-method (Livak and Schmittgen 2001) with actin as the reference gene. Primers for actin are based on $A$. thaliana actin (At3g18780). Primer pairs used for qPCR are listed in Table 1 and are based on following mRNA sequences: EcP5ßR1, GU354236 (Munkert et al. 2011); EcP5ßR2, KF234078 (Munkert et al. 2015); Ec-

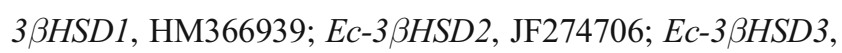
MT978165 (Munkert et al. 2014).

Cardenolide extraction and determination Cardenolides were extracted from plant and shoot samples as described by Wiegrebe and Wichtl (1993). The extracts were analyzed by HPLC according to Wichtl et al. (1982) with slight modifications (Schebitz et al. 2010). For HPLC analysis, a Waters 1525 Binary HPLC Pump system with a Waters 2487 Dual

Table 1. Primer pairs used for $\mathrm{qPCR}$

\begin{tabular}{|c|c|}
\hline Name & Sequence in $5^{\prime}-3$ 'direction \\
\hline qEcP5 $\beta R 1$ for: & GTCCCACACGCGCCTAATCT \\
\hline qEcP5 $\beta$ R1 rev: & AGTAAAAGGCGGATCGTGGC \\
\hline qEcP5 $\beta \mathrm{R} 2$ for: & CAATGGCTCGTGGAGAAGGT \\
\hline qEcP5 $\beta \mathrm{R} 2$ rev: & ACCGACCAAACAACGGAACT \\
\hline qEc3ßHSD1 for: & ATG TCT GGA AAA AGA TTG GAT GG \\
\hline qEc3ßHSD1 rev: & ATC CAC CAG AAG CTG TTT TGA T \\
\hline qEc3ßHSD2 for: & GGG CTA GAG AAA GCA ACG TTT T \\
\hline qEc3ßHSD2 rev: & GCT CGT GGT ACA TAC GAT TGA C \\
\hline qEc3ßHSD3 for: & CGA TGT TAC GAA CGA GAC AGA G \\
\hline qEc3 3 HSD3 rev: & CTC AGA CGT AAC GCT GGT TGT A \\
\hline
\end{tabular}


k Absorbance Detector was employed (Waters GmbH, Eschborn, Germany). The separation was carried out on a ReproSil® column $(\mathrm{C} 18,5 \mathrm{lM}, 4.6 \times 250 \mathrm{~mm})$, eluting with a step gradient composed of double-distilled water (solvent $\mathrm{A}$ ) and acetonitrile (solvent B): start (20\%B), 20 min (32\%B), $7 \mathrm{~min}(42 \% \mathrm{~B}), 13 \mathrm{~min}(60 \% \mathrm{~B}), 19 \mathrm{~min}(100 \% \mathrm{~B})$, and $6 \mathrm{~min}$ $(20 \% \mathrm{~B})$. Erysimoside and helveticoside were detected and quantified at $220 \mathrm{~nm}$ using a UV detector. Erysimoside and helveticoside standards were purchased from Merck KGaA (Darmstadt, Germany) and $\beta$-methyldigitoxin served as the internal standard for quantification. In several experiments, cardenolides were hydrolyzed prior to quantification ("total cardenolides") following the protocol of Mannich and Siewert (1942) with slight modifications only.

Glucosinolates Glucosinolates were extracted as described by Meitinger and Kreis (2018). For extraction, $1 \mathrm{mg}$ ascorbic acid as well as $250 \mu \mathrm{L}$ of a sinigrin solution was added to $0.35 \mathrm{~g}$ of fresh plant material until a final concentration of $1.8 \mathrm{mM}$ was reached. In order to ensure complete hydrolysis of endogenous glucosinolates, myrosinase prepared from mustard seeds (Meitinger and Kreis 2018) was added.

After $2 \mathrm{~h}$ of incubation at $23^{\circ} \mathrm{C}$ and $10 \mathrm{~min}$ of centrifugation at $10,000 g, 3 \mu \mathrm{g} \mu \mathrm{L}^{-1}$ benzylisothiocyanate was added as an internal standard and the supernatant extracted with dichloromethane. After separation, the organic phase was analyzed by GC-MS using the following conditions: DB- $5 \mathrm{~ms}$ (Agilent Technologies Deutschland GmbH, Waldbronn, Germany) column $(30 \mathrm{~m} \times 0.25 \mathrm{~mm}$, film $0.25 \mu \mathrm{m})$; column oven temperature: $60^{\circ} \mathrm{C}$; injector temperature: $230^{\circ} \mathrm{C}$; injection volume: $1 \mu \mathrm{L}$; split ratio: $1: 100$; ion source temperature: $200^{\circ} \mathrm{C}$; interface temperature: $210^{\circ} \mathrm{C}$; and MS in scan mode: $35-200 \mathrm{~m} / \mathrm{z}$. The temperature gradient with helium as the carrier gas was implemented at a flow rate of $46.3 \mathrm{~cm} \mathrm{~s}^{-1}$. The temperature was kept constant for $3 \mathrm{~min}$ at $60^{\circ} \mathrm{C}$ before it was increased to $210^{\circ} \mathrm{C}$ at a rate of $10^{\circ} \mathrm{C}$ per min.

\section{Results and discussion}

Micropropagation protocol of Erysimum crepidifolium Rchb. Surface-sterilized single seeds were placed on a modified MS solid medium containing $2 \mathrm{mg} \mathrm{L}^{-1} \mathrm{BAP}$ (DDV). In previous studies, BAP proved to be the most suitable phytohormone to initiate shoot multiplication without root formation (Zimmerman and Scorza 1992).

Alternatively, rooting was induced on solid media supplemented with NAA. Murashige and Skoog (1962) previously reported that NAA is a more potent auxin than natural occurring indoleacetic acid (IAA). We here tested 20 different combinations of BAP and NAA in order to initiate root formation. Optimal results were achieved when liquid MS medium containing $2 \mathrm{mg} \mathrm{L}^{-1} \mathrm{BAP}$ and $40 \mathrm{mg} \mathrm{L}^{-1}$ NAA was used and root formation began after 2 wk. George and Sherrington (1984) also reported that rooting can be induced with a nutrient medium containing high auxin and low cytokinin concentration. Even higher concentrations of BAP and NAA stimulated callus formation as had been reported before for other plants (Hussey and Stacey 1981; Iriondo 1990a, 1990b).

Plantlets were transferred onto solid, hormone-free MS medium after $6 \mathrm{wk}$ on rooting medium. After an additional $8 \mathrm{wk}$, the plantlets were ready to be potted (Fig. $2 a-d$ ). Plantlets were transferred to the greenhouse and kept initially on a sterilized mixture of sand and soil to avoid microbial damage. Shoot cultures grown in vitro fail to form sufficient layers of epicuticular wax (Grout and Aston 1977; Sutter and Langhans 1979). In order to still guarantee a humid atmosphere, the plantlets were kept in seeding boxes for 3 more wk. Two months after their transfer to the greenhouse, $77.5 \%$ of the plants had survived and became well developed (Fig. 2d). This protocol provides genetically homogenous plants that can be used in further studies; however, vegetative propagation by scions and runners is also feasible (unpublished observations).

Glucosinolates and cardenolides in permanent cultures and during regeneration Developing shoots from stock cultures on solid medium were transferred into liquid MS medium for further proliferation. Cultivation in liquid medium facilitates the delivery of biosynthetic precursors or chemical stressors and makes it easier to monitor an increase in biomass (Fig. 2b). Permanent shoot cultures are suitable for studying the regulation of cardenolide biosynthesis or for detailed analyses of the influence of light and chloroplast differentiation which has been demonstrated in somatic embryos of $D$. lanata (Scheibner et al. 1989). After transfer into liquid medium, E. crepidifolium shoots developed an abnormal, clinched phenotype (Fig. 2a). The chlorophyll content was $0.3 \mathrm{mg}$ to $0.9 \mathrm{mg} \mathrm{g}^{-1}$ fresh weight (FW) and the biomass only doubled within 3 wk. A $30 \mathrm{mg} \mathrm{mL}^{-1}$ glucose medium was provided after $30 \mathrm{~d}$ of culture, and the partially submerged shoot cultures accumulated neither glucosinolates nor cardenolides (see below). On the solid DDV medium, shoot tufts developed successfully (Fig. 2c) and could be propagated easily. Shoot cultures kept at these conditions contained cardenolides but no glucosinolates (see below).

Glucosinolates The glucosinolate content was calculated from iberin released from glucoiberin by the action of myrosinase (Fig. 1). Myrosinase from mustard seeds was added to ensure the complete conversion of glucosinolates to their respective isothiocyanates since the endogenous myrosinase activity was very low from shoots cultured in liquid medium (data not shown). Hydrolysis of glucosinolates usually occurs when plant tissue is damaged and glucosinolates come in contact with endogenous myrosinases (Rask et al. 2000; Vaughn 
and Berhow 2005; Loebers et al. 2014). After prolonged cultivation on a solid hormone-free medium, E. crepidifolium shoot cultures contained $0.025 \pm 0.01 \mathrm{mg} \mathrm{g}^{-1} \mathrm{FW}(n=3)$ glucosinolates. Glucosinolates did not accumulate in shoots cultured in a liquid medium (Table 2).

Only low levels of glucosinolates were detected in leaves of greenhouse plants (Table 2). The glucosinolate content of roots was considerably higher and reached $4.55 \mathrm{mg}$ iberin $\mathrm{g}^{-1}$ FW. Concentrations as high as $5 \%$ of the dry seed mass were reported for individual glucosinolates in flowers and seeds (Bennett et al. 2004).

Cardenolides E. crepidifolium accumulates approximately $1 \%$ cardenolides in the dry mass of its above ground organs, most of them bearing k-strophanthidin (str) as their aglycone. Digitoxose (dox) and glucose (glc) are the sugar components of the main glycosides erysimoside (str-dox-glc) and helveticoside (str-dox), representing about $90 \%$ of the cardenolide mixture (Fig. 1; Gmelin and Bredenberg 1966). Since only traces of the minor cardenolides such as erycordin and glucostrophalloside (Makarevich et al. 1974) were detected, we only quantified erysimoside and helveticoside either individually or as their degradation product, k-strophanthidin, released by chemical hydrolysis of the cardenolide extract (Fig. 1). Approximately $80 \mu \mathrm{g} \mathrm{g}^{-1} \mathrm{FW}$ cardenolides were detected in shoots cultivated on the DDV medium even after prolonged subculture for more than $2 \mathrm{y}$. The concentrations decreased dramatically when stock shoot cultures were transferred from the solid into the liquid DDV medium where they developed an abnormal phenotype (Fig. 2a). While minor amounts of cardenolides were still present after $3 \mathrm{wk}$ in liquid medium (about $10 \mu \mathrm{g} \mathrm{g}^{-1} \mathrm{FW}$ ), they had vanished completely after two mo. Cardenolide formation also ceased when shoots were kept on the solid DDV medium but cultivated in permanent darkness. After $1 \mathrm{wk}$, the cardenolide content dropped down to $10 \%$ of that seen in control shoots grown at standard

Table 2. Accumulation of glucosinolates (iberin released from glucoiberin) and cardenolide (k-strophanthidin released from erysimoside and helveticoside) in greenhouse Erysimum crepidifolium Rchb. plants and shoot cultures (mean \pm STD, $n=3$ )

\begin{tabular}{lll}
\hline Plant part & Iberin $\left(\mathrm{mg} \mathrm{g}^{-1} \mathrm{FW}\right)$ & Cardenolides $\left(\mathrm{mg} \mathrm{g}^{-1} \mathrm{DW}\right)$ \\
\hline Shoot culture (liquid) & n.d. & $0.47 \pm 0.27$ \\
Shoot culture (solid) & $0.025 \pm 0.01$ & $1.75 \pm 0.85$ \\
Young leaves & $0.41 \pm 0.02$ & $0.38 \pm 0.19$ \\
Mature leaves & $0.11 \pm 0.01$ & Traces \\
Main root & $4.55 \pm 1.37$ & Traces \\
Adventitious roots & $0.52 \pm 0.02$ & n.d \\
\hline
\end{tabular}

n.d., not detectable

$F W$, fresh weight; $D W$, dry weight

Traces: less than $0.01 \mathrm{mg} \mathrm{g}^{-1} \mathrm{DW}$ conditions. This was paralleled by the degradation of chlorophyll which dropped from 0.3 to $0.03 \mathrm{mg} \mathrm{g}^{-1} \mathrm{FW}$ within $12 \mathrm{~d}$.

This corroborates the findings of others (Luckner and Diettrich 1985; Eisenbeiß et al. 1999) who demonstrated that cardenolide formation depends on morphological differentiation and light. This is also consistent with observations concerning other natural compounds. For example, Coste et al. (2011) reported that hypericin biosynthesis is impaired after transfer from a solid into a liquid culture medium. Hugentobler and Renwick (1995) discussed possible reasons for differential formation of cardenolides and glucosinolates in Erysimum as a result of nutrient deficiency. Shoots transferred into rooting medium also ceased to produce cardenolides which can be explained by the altered medium composition (Table 2; $0.04 \mathrm{mg} \mathrm{mL}^{-1} \mathrm{NAA}$ ) as was suggested by Patil et al. (2013). Plantlets grown on the hormone-free medium prior to their transfer into soil produced only minor quantities of cardenolides. However, cardenolides accumulated in a similar range in young leaves $\left(0.38 \mathrm{mg} \mathrm{g}^{-1}\right.$ dry weight (DW)) of Erysimum crepidifolium plants as in liquid shoot cultures $\left(0.47 \mathrm{mg} \mathrm{g}^{-1} \mathrm{DW}\right)$, but did not reach cardenolide levels of shoot cultures that were cultured on solid media (Table 2).

Expression of two EcP5 $\beta R$ genes and three Ec3 $3-H S D$ genes in $E$. crepidfolium shoot cultures Other than the cardenolide content, gene expression levels of $E c P 5 \beta R \mathrm{~s}$ and $E c 3 \beta$-HSDs were measured since the encoded enzymes, namely, progesterone $5 \beta$-reductase and $\Delta^{5}-3 \beta$ hydroxysteroid dehydrogenases, are reported to be involved in cardenolide biosynthesis in Digitalis (Kreis and Müller-Uri 2010, 2013). Two EcP5 $\beta R$ $(E c P 5 \beta R 1 ; E c P 5 \beta R 2)$ genes have been reported to be expressed in E. crepidifolium greenhouse plants by Munkert et al. $(2011,2015)$ who also characterized recombinant forms of the encoded progesterone $5 \beta$-reductases. In permanent shoot cultures (solid medium), the expression of EcP5 $\beta R 1$ was about six times higher than that of $E c P 5 \beta R 2$ (Fig. $3 a$ ). The expression of $E c P 5 \beta R 2$, but not $E c P 5 \beta R 1$, was stimulated by abiotic stress. When treated with 2-cyclohexen-1-one or methyl vinyl ketone (MVK), expression increased 6.8-fold and 3.4-fold, respectively, after $24 \mathrm{~h}$, after $7 \mathrm{~d}$, basic expression levels, similar to levels prior to abiotic stress treatment, were reached (Fig. $3 b$ ). Heterologous $P 5 \beta R 1$ of $D$. purpurea was also expressed constitutively in plants, whereas the expression $P 5 \beta R 2$ dramatically increased in stress conditions (Pérez-Bermúdez et al. 2010).

Munkert et al. (2014) identified three genes (Ec3 $\beta$-HSD1;

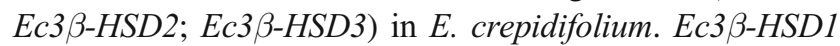
did not respond to various forms of stress, whereas $E c 3 \beta$ $H S D 2$ and $E c 3 \beta-H S D 2$ were upregulated when plants were treated with methyl jasmonate or methyl vinyl ketone. We observed that during rooting, the expression levels of $E c 3 \beta$ - 

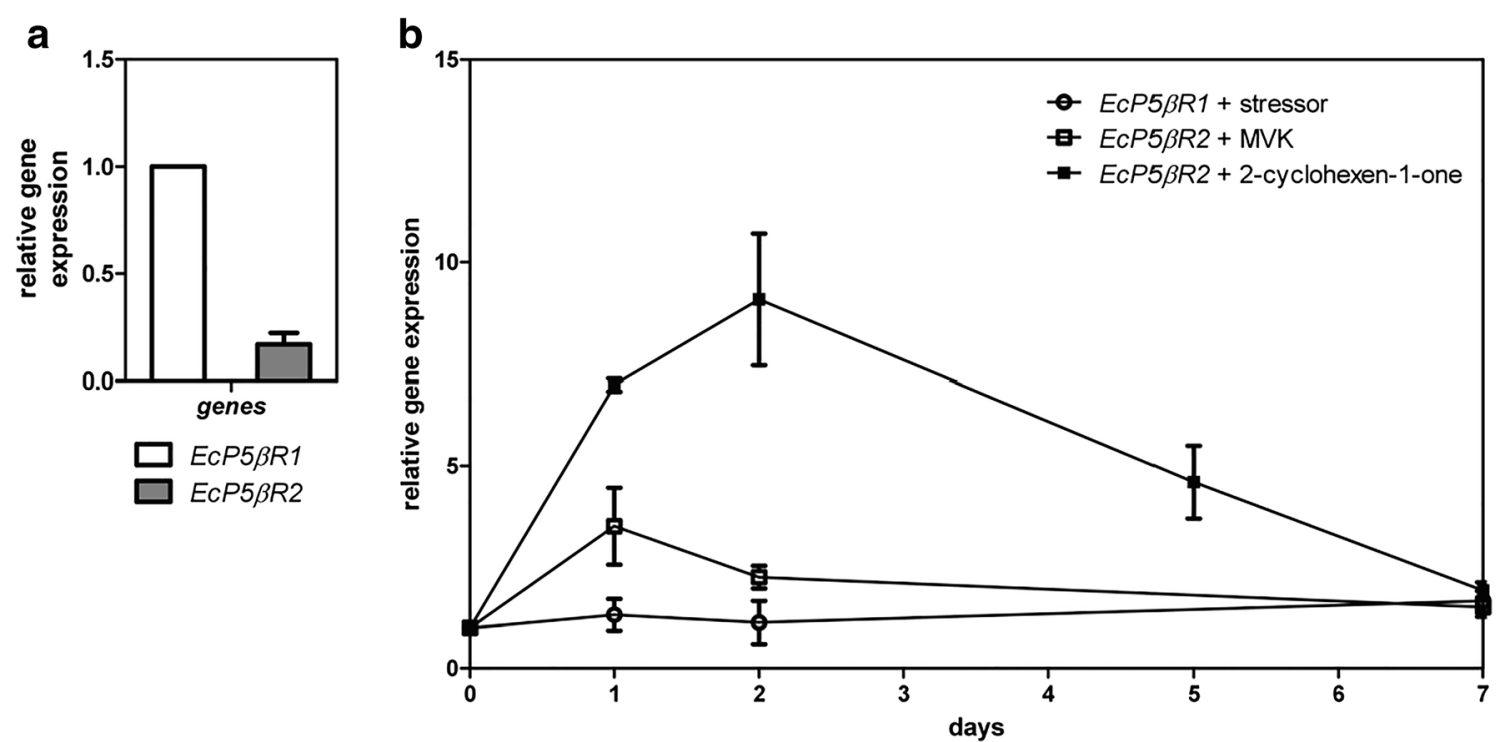

Figure 3. Relative gene expression of Erysimum crepidifolium Rchb. progesterone $5 \beta$-reductase 1 and 2 (EcP5 $\beta R 1$; EcP5 $\beta R 2)$. (a) Relative expression level of $E c P 5 \beta R 2$ to $E c P 5 \beta R 1$ normalized on actin. (b)

Relative gene expression of $E c P 5 \beta R 1$ and $E c P 5 \beta R 2$ normalized on actin, when shoots were treated with 2-cyclohexen-1-one or methyl vinyl ketone (MVK).

$H S D 1$ remained almost constant, whereas the expression level of $E c 3 \beta-H S D 2$ and $E c 3 \beta-H S D 3$ increased by almost eightfold immediately after transfer to the rooting medium which was interpreted as a stress response (data not shown). Exposing 4mo-old plants to various stress conditions, Munkert et al. (2014) found that cardenolide content paralleled gene expression of Ec3 $3-H S D 2$ and $E c 3 \beta-H S D 3$ in several but not all tested stress conditions. In our studies, shoots grown in liquid medium developed an abnormal phenotype and did not accumulate cardenolides although Ec3 $\beta-H S D 2$ and $E c 3 \beta-H S D 3$ were upregulated. This indicates that morphological differentiation plays a pivotal role in triggering cardenolide formation and that $E c 3 \beta$-HSDs may also be involved in other physiological processes.
After rooting and transfer to solid medium, the relative expression of $E c 3 \beta-H S D 1$ steadily increased from 0.51 to 4.19 and thus paralleled cardenolide accumulation, whereas the expression levels of $E c 3 \beta-H S D 2$ and $E c 3 \beta$-HSD 3 remained nearly unaffected. $E c 3 \beta-H S D 1$ expression seems to be related to plant development and differentiation, including cardenolide formation, whereas $E c 3 \beta-H S D 2$ and $E c 3 \beta$ $H S D 3$ are stress-sensitive (Fig. $4 a, b$ ).

All three $3 \beta-H S D$ isoforms investigated here were expressed in each phase of the regeneration protocol and in permanent shoot cultures in stages with or without cardenolide accumulation. Similar results were obtained for $3 \beta-H S D$ and P5 $3 R 1$ of Digitalis lanata (Ernst et al. 2010); the latter is considered to be a key enzyme in cardenolide biosynthesis (Herl et al. 2008). Like the $3 \beta-H S D 1$ of E. crepidifolium,
Figure 4. (a) Cardenolide content (k-strophanthidin) after transfer of tuft-like structures to solid DDV medium. In developing Erysimum crepidifolium Rchb. shoots (dark gray) cardenolide formation increased. Tuft-like structures (callus) still present after 31 to $52 \mathrm{~d}$ continued to contain small amounts of cardenolides (light gray). Mean ( \pm STD; $n=3)$. (b) Relative gene expression level of $E c-3 \beta H S D 1, E c-3 \beta H S D 2$ to Ec$3 \beta H S D 3$ normalized on actin. a

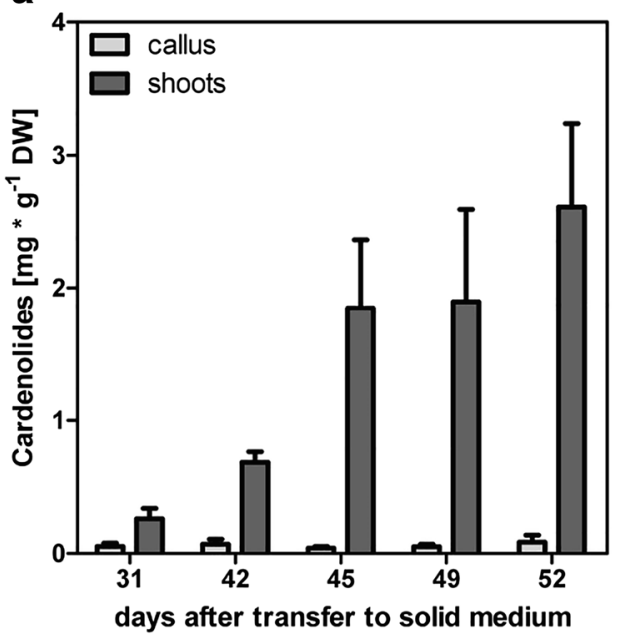

b

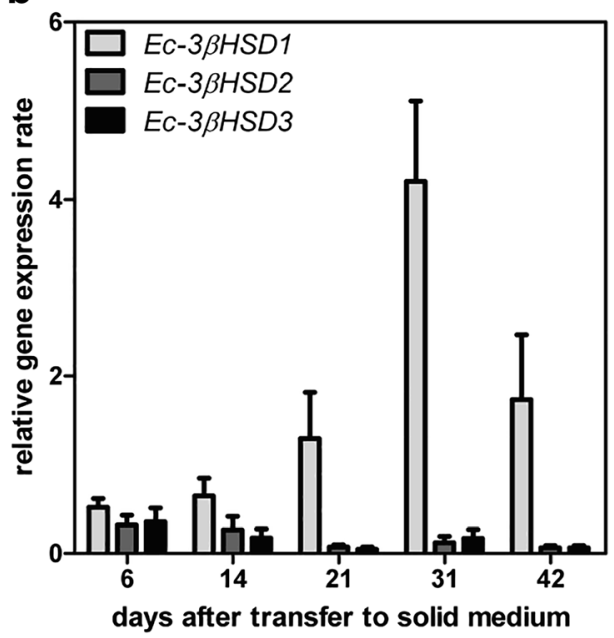


the $P 5 \beta R 1$ of $D$. purpurea was expressed constitutively in plants. The expression $P 5 \beta R 2$ was mainly induced by stress (Pérez-Bermúdez et al. 2010).

Like the glucosinolates, cardenolides were only detected after shoot differentiation and during plant regeneration. Cardenolide formation returned after approximately 2 mo on solid medium (Fig. $4 a$ ) but did not correlate with the expression of the $3 \beta-H S D$ genes. Cardenolide content and pattern can change during plant growth and development as has been demonstrated widely for Digitalis species (Weiler and Zenk 1976; Wichtl and Freier 1978; Braga et al. 1997).

\section{Conclusion}

We conclude that E. crepidifolium shoot cultures propagated on solid and liquid media meet the essential requirements (clonal homogeneity, cardenolide production) of a suitable model to study cardenolide but not glucosinolate biosynthesis. The development of this micropropagation protocol additionally offers access to genetically identical mature plants for future studies.

Acknowledgments We thank Barbara White for linguistic advice and Gabriele Fischer for assistance in editing the manuscript. We further thank the group of the Molecular Urology Department (University Clinic FAU) for the extensive use of the real-time PCR machine.

Authors' contributions All authors contributed to the study conception and design. WK and JM designed the study. Material preparation, data collection, and analysis were performed by EH and YK. The first draft of the manuscript was written by WK, EH, and JM. Further, all authors commented on previous versions of the manuscript. All authors read and approved the final manuscript.

Funding Open Access funding enabled and organized by Projekt DEAL.

Open Access This article is licensed under a Creative Commons Attribution 4.0 International License, which permits use, sharing, adaptation, distribution and reproduction in any medium or format, as long as you give appropriate credit to the original author(s) and the source, provide a link to the Creative Commons licence, and indicate if changes were made. The images or other third party material in this article are included in the article's Creative Commons licence, unless indicated otherwise in a credit line to the material. If material is not included in the article's Creative Commons licence and your intended use is not permitted by statutory regulation or exceeds the permitted use, you will need to obtain permission directly from the copyright holder. To view a copy of this licence, visit http://creativecommons.org/licenses/by/4.0/.

\section{References}

Arikat NA, Jawad FM, Karam NS, Shibli RA (2004) Micropropagation and accumulation of essential oils in wild sage (Salvia fruticosa Mill.). Sci Hortic 100:193-202
Bailey CD, Koch MA, Mayer M, Mummenhoff K, O'Kane SL, Warwick SI, Windham MD, Al-Shehbaz IA (2006) Toward a global phylogeny of the Brassicaceae. Mol Biol Evol 23:2142-2160

Bennett RN, Mellon FA, Kroon PA (2004) Screening crucifer seeds as sources of specific intact glucosinolates using ion-pair high-performance liquid chromatography negative ion electrospray mass spectrometry. J Agric Food Chem 52:428-438

Braga FC, Kreis W, Récio RA, de Oliveira AB (1997) Variation of cardenolides with growth in a Digitalis lanata Brazilian cultivar. Phytochemistry 45:473-476

Burger A, Wachter H (1998) Hunnius pharmazeutisches Wörterbuch, 8th edn. de Gruyter, Berlin

Coste A, Vlase L, Halmagyi A, Deliu C, Coldea G (2011) Effects of plant growth regulators and elicitors on production of secondary metabolites in shoot cultures of Hypericum hirsutum and Hypericum maculatum. Plant Cell Tissue Organ Cult 106:279-288

Eisenbeiß M, Kreis W, Reinhard E (1999) Cardenolide biosynthesis in light- and dark-grown Digitalis lanata shoot cultures. Plant Physiol Biochem 37:13-23

Ernst M, Padua RM, Herl V, Müller-Uri F, Kreis W (2010) Expression of $3 \beta$-HSD and P $5 \beta$ R, genes respectively coding for $\Delta 5-3 \beta$-hydroxysteroid dehydrogenase and progesterone $5 \beta$-reductase, in leaves and cell cultures of Digitalis lanata EHRH. Planta Med 76:923-927

Fahey JW, Zalcmann AT, Talalay P (2001) The chemical diversity and distribution of glucosinolates and isothiocyanates among plants. Phytochemistry 56:5-51

George EF, Sherrington PD (1984) Plant propagation by tissue culture: handbook of directory of commercial laboratories. Exegetics, Basingstoke, Hants

Gmelin R, Bredenberg JB son (1966) Untersuchungen über Inhaltsstoffe einiger Erysimum-Arten: a) Identifizierung des Bitterstoffs Erysimupikron als Strophanthidia; b) Glucosinlate in den Samen von Erysimum perofskianum Fisch et Mey., E. allionii hort., E. crepidifolium Rchb. und E. cheiranthoides L. ArzneimittelForschung 16:123-127

Grout BWW, Aston MJ (1977) Transplanting of cauliflower plants regenerated from meristem culture. I. Water loss and water transfer related to changes in leaf wax and to xylem regeneration. Hortic Res: $1-7$

Herl V, Albach DC, Müller-Uri F, Bräuchler C, Heubl G, Kreis W (2008) Using progesterone $5 \beta$-reductase, a gene encoding a key enzyme in the cardenolide biosynthesis, to infer the phylogeny of the genus Digitalis. Plant Syst Evol 271:65-78

Hugentobler U, Renwick JAA (1995) Effects of plant nutrition on the balance of insect relevant cardenolides and glucosinolates in Erysimum cheiranthoides. Oecologia 102:95-101

Hussey G, Stacey NJ (1981) In Vitro propagation of potato (Solanum tuberosum L.). Ann Bot 48:787-796

Iriondo M (1990a) A late Holocene dry period in the argentine plains. In: Rabassa J, Salemme M (eds) Quaternary of South America and Antarctic Peninsula, 7th edn. Aimé Balkema, Rotterdam, pp 197218

Iriondo M (1990b) Map of the South American plains - its present state. In: Rabassa J, Salemme M (eds) Quaternary of South America and Antarctic Peninsula, 7th edn. Aimé Balkema, Rotterdam, pp 297308

Jaretzky R, Wilcke M (1932) Die herzwirksamen Glykoside von Cheiranthus cheiri und verwandten Arten. Arch Pharm Pharm Med Chem 270:81-94

Kreis W (2017) The foxgloves (Digitalis) revisited. Planta Med 83:962976

Kreis W, Haug B, Yücesan B (2015) Somaclonal variation of cardenolide content in Heywood's foxglove, a source for the antiviral cardenolide glucoevatromonoside, regenerated from permanent shoot culture and callus. In Vitro Cell Dev Biol - Plant 51:35-41 
Kreis W, Müller-Uri F (2010) Biochemistry of sterols, cardiac glycosides, Brassinosteroids, phytoecdysteroids and steroid saponins. In: Wink $M$ (ed) Biochemistry of plant secondary metabolism. WileyBlackwell, Oxford, pp 304-363

Kreis W, Müller-Uri F (2013) Cardenolide aglycone formation in Digitalis. In: Bach TJ, Rohmer M (eds) Isoprenoid synthesis in plants and microorganisms. Springer New York, New York, NY, pp 425-438

Livak KJ, Schmittgen TD (2001) Analysis of relative gene expression data using real-time quantitative PCR and the $2^{-\Delta \Delta C}$ method. Methods 25:402-408

Loebers A, Müller-Uri F, Kreis W (2014) A young root-specific gene (ArMY2) from horseradish encoding a MYR II myrosinase with kinetic preference for the root-specific glucosinolate gluconasturtiin. Phytochemistry 99:26-35

Luckner M, Diettrich B (1985) Formation of cardenolides in cell and organ cultures of Digitalis lanata. In: Neumann K-H, Barz W, Reinhard E (eds) Primary and secondary metabolism of plant cell cultures. Springer, Berlin Heidelberg, pp 154-163

Makarevich IF, Klimenko OI, Kolesnikov DG (1974) Cardiac glycosides of Erysimum crepidifolium. Chem Nat Compd 10:619-622

Makarevich IF, Zhernoklev KV, Slyusarskaya TV, Yarmolenko GN (1994) Cardenolide-containing plants of the family Cruciferae. Chem Nat Compd 30:275-289

Mannich C, Siewert G (1942) Über g-Strophanthin (Ouabain) und gStrophanthidin. Ber dtsch Chem Ges A/B 75:737-750

Matile P (1980) "Die Senfölbombe": Zur Kompartimentierung des Myrosinasesystems "the mustard oil bomb": compartmentation of the myrosinase system. Biochem Physiol Pflanz 175:722-731

Meitinger N, Kreis W (2018) Development and validation of a quick assay for the total glucosinolate content in horseradish (Armoracia rusticana) using glucose strips and a blood glucose meter. J Appl Bot Food Qual 91:232-236

Munkert J, Bauer P, Burda E, Müller-Uri F, Kreis W (2011) Progesterone $5 \beta$-reductase of Erysimum crepidifolium: cDNA cloning, expression in Escherichia coli, and reduction of enones with the recombinant protein. Phytochemistry 72:1710-1717

Munkert J, Ernst M, Müller-Uri F, Kreis W (2014) Identification and stress-induced expression of three $3 \beta$-hydroxysteroid dehydrogenases from Erysimum crepidifolium Rchb. And their putative role in cardenolide biosynthesis. Phytochemistry 100:26-33

Munkert J, Pollier J, Miettinen K, van Moerkercke A, Payne R, MüllerUri F, Burlat V, O'Connor SE, Memelink J, Kreis W, Goossens A (2015) Iridoid synthase activity is common among the plant progesterone 5 $\beta$-reductase family. Molecul Plant 8:136-152

Murashige T, Skoog F (1962) A revised medium for rapid growth and bio assays with tobacco tissue cultures. Physiol Plant 15:473-497

Nielsen JK (1978a) Host plant discrimination within Cruciferae: feeding responses of four leaf beetles (Coleoptera: Chrysomelidae) to glucosinolates, cucurbitacins and cardenolides. Entomol Exp Appl 24: $41-54$

Nielsen JK (1978b) Host plant selection of monophagous and oligophagous flea beetles feeding on crucifers. Entomol Exp Appl 24:562569

Patil JG, Ahire ML, Nitnaware KM, Panda S, Bhatt VP, Kishor PBK, Nikam TD (2013) In vitro propagation and production of cardiotonic glycosides in shoot cultures of Digitalis purpurea L. by elicitation and precursor feeding. Appl Microbiol Biotechnol 97:2379-2393

Pérez-Bermúdez P, García AAM, Tunón I, Gavidia I (2010) Digitalis purpurea P5 $\beta \mathrm{R} 2$, encoding steroid $5 \beta$-reductase, is a novel defense-related gene involved in cardenolide biosynthesis. New Phytol 185:687-700

Polatschek A (2013a) Revision der Gattung Erysimum (Cruciferae): Teil 4. Nordafrika, Malta, Zypern. Ann Naturhist Mus Wien Ser B 115: 57-74

Polatschek A (2013b) Revision der Gattung Erysimum (Cruciferae): Teil 5. Nord-, West-, Zentraleuropa, Rumänien und westliche BalkanHalbinsel bis Albanien. Ann Naturhist Mus Wien B 115:75-218

Rask L, Andréasson E, Ekbom B, Eriksson S, Pontoppidan B, Meijer J (2000) Myrosinase: gene family evolution and herbivore defense in Brassicaceae. Plant Mol Biol 42:93-114

Schebitz P, Nothdurft L, Hensel A, Müller-Uri F, Kreis W (2010) Norcholanic acids as substrates for recombinant $3 \beta$ hydroxysteroid dehydrogenase and progesterone $5 \beta$-reductase, enzymes of the $5 \beta$-cardenolide biosynthesis. Tetrahedron Lett 51 : 367-370

Scheibner H, Diettrich B, Schulz U, Luckner M (1989) Somatic embryos of Digitalis lanata synchronization of development and cardenolide biosynthesis. Biochem Physiol Pflanz 184:311-320

Schöner G, Haken H, Kelso JA (1986) A stochastic theory of phase transitions in human hand movement. Biol Cybern 53:247-257

Sutter E, Langhans RW (1979) Epicuticular wax formation on carnation plantlets regenerated from shoot tip culture. J Am Soc Hortic Sci: 493-496

Vaughn SF, Berhow MA (2005) Glucosinolate hydrolysis products from various plant sources: $\mathrm{pH}$ effects, isolation, and purification. Ind Crop Prod 21:193-202

Weiler EW, Zenk MH (1976) Radioimmunoassay for the determination of digoxin and related compounds in Digitalis lanata. Phytochemistry 15:1537-1545

Wichtl M, Freier R (1978) Veränderungen der Zusammensetzung des Glykosidgemisches in den Blättern von Digitalis lanata Ehrh. im Verlaufe der ersten Vegetationsperiode. Deutsche Apotheker Zeitung 118:798-802

Wichtl M, Mangkudidjojo M, Wichtl-Bleier W (1982) Hochleistungsflüssigkeits-chromatographische analyse von DigitalisBlattextrakten. J Chromatogr A 234:503-508

Wiegrebe H, Wichtl M (1993) High-performance liquid chromatographic determination of cardenolides in Digitalis leaves after solid-phase extraction. J Chromatogr A 630:402-407

Winde I, Wittstock U (2011) Insect herbivore counteradaptations to the plant glucosinolate-myrosinase system. Phytochemistry 72:15661575

Zhu YC, Wu CD, Li JF (1989) Plantae medicinales chinae borealiorientalis. Heilongjiang Science and Technology Publishing House, Harbin, p 463

Zimmerman TW, Scorza R (1992) Shoot growth and proliferation of peach under varying environmental regimes. HortSci 27:696a$6696 \mathrm{a}$

Züst T, Mirzaei M, Jander G (2018) Erysimum cheiranthoides, an ecological research system with potential as a genetic and genomic model for studying cardiac glycoside biosynthesis. Phytochem Rev 17:1239-1251

Züst T, Strickler SR, Powell AF, Mabry ME, An H, Mirzaei M, York T, Holland CK, Kumar P, Erb M, Petschenka G, Gómez J-M, Perfectti F, Müller C, Pires JC, Mueller LA, Jander G (2020) Independent evolution of ancestral and novel defenses in a genus of toxic plants (Erysimum, Brassicaceae). eLife 9:e51712 